\title{
Transformasi Pecandu Penyandang HIV/AIDS Menjadi Konselor Adiksi: Sebuah Kajian Life History
}

\section{From an Addicted Person with HIV/AIDS to an Addiction Counselor: A Life History}

\author{
Qori Faizun, Nurchayati \\ Program Studi Psikologi Universitas Negeri Surabaya, Surabaya, Indonesia
}

\begin{abstract}
Using Giddens' structuration theory and Bandura's concept of agency, this quasi-life-historical study deals with how an interplay between agency and social structure produced the transformation of a participant from a drug addict with HIV/AIDS into an addiction counselor. In response to the structural forces at work in her society, the subject exercised her agency in ways that led, as an unintended consequence, to her contracting HIV/AIDS. Drug abuse, too, was another of her selfdefeating ways of tackling life's trials, such as the excess of pocket money, dysfunctional family communications, and stifling parental disciplinary styles. Structural forces, taking the forms of rehabilitation facilities and family and community supports, played a key role in her success in kicking her drug habit and becoming an addiction counselor. The transformation, however, is best seen as the product of a favorable interplay between existing structural forces and the subject's constructive ways of enacting her agency.
\end{abstract}

Keywords: Agency, structure, drug addict, HIV/AIDS, addiction counselor

\begin{abstract}
Abstrak: Menggunakan metode quasi-life history, riset kualitatif ini mengkaji transformasi subjek dari pecandu penyandang HIV/AIDS menjadi konselor adiksi. Merujuk pada teori strukturasi Giddens dan konsep agency dari Bandura, studi ini mencoba memahami bagaimana struktur dan agency berinteraksi dan menghasilkan transformasi tersebut. Menjadi penyandang HIV/AIDS adalah akibat yang tidak diniatkan (unintended consequence) dari cara subjek menjalankan agency-nya dalam menanggapi daya-daya struktural dalam masyarakat. Dalam menyikapi peraturan orang tua, ketidakharmonisan komunikasi keluarga dan berlebihnya uang saku, subjek justru mengonsumsi NAPZA. Di sisi lain, ada sejumlah daya struktural yang membantu subjek membebaskan diri dari adiksi dan menjadi konselor, seperti program rehabilitasi, dukungan masyarakat sekitar, dan membaiknya sikap keluarga. Alih-alih bekerja sendiri, daya-daya struktural tersebut bersinergi dengan perjuangan subjek. Studi ini menyimpulkan bahwa transformasi subjek dari pencandu NAPZA dan penyandang HIV/AIDS menjadi konselor adiksi dapat dipahami sebagai hasil sinergi antara agency individu dan struktur sosial.
\end{abstract}

Kata kunci: Agency, struktur, pecandu, HIV/AIDS, konselor adiksi

Dari tahun ke tahun, jumlah penyandang HIV/AIDS terus bertambah. Menurut WHO, sampai akhir 2018, jumlah penyan- dang HIV/AIDS dunia meningkat 4,69\%, dari 36,2 ke 37,9 juta orang. Demikian pula, kasus HIV/AIDS di tanah air juga

Korespondensi tentang artikel ini dapat dialamatkan kepada Nurchayati melalui e-mail: nurchayati@unesa.ac.id 
terus menanjak, dari 29.037 pada 2013 dan 32.711 pada 2014 menjadi 41.250 pada tahun 2016 dan 48.300 pada tahun 2017 (Kemenkes RI, 2018).

Para penyandang HIV/AIDS menghadapi banyak tantangan. Mereka harus menanggung beban ganda, mulai dari fisik dan psikis sampai sosial dan ekonomi. Secara fisik, akibat merosotnya kekebalan tubuh, mereka rawan serangan berbagai penyakit. Dalam masyarakat, mereka menjadi objek stigma. Sebagai salah satu akibat miskinnya pengetahuan masyarakat tentang mekanisme penularan HIV, stigma tersebut, dan penghakiman yang tak adil, mendorong sebagian masyarakat memperlakukan penyandang HIV/AIDS dalam cara yang diskriminatif (Herek, Capitanio, \& Widaman, 2002). Diskriminasi ini hadir dalam berbagai wujud, misalnya menghindari persentuhan fisik, menolak berkegiatan bersama, dan menghindari berada dalam satu ruang dengan penyandang HIV/AIDS. Argumen Herek, Capitanio, dan Widaman dikonfirmasi oleh Pardita dan Sudibia (2014) yang menemukan bahwa di Denpasar, Bali, intensitas pertemuan antara penyandang HIV/AIDS dan para tetangga mereka, misalnya dalam berbagai upacara adat dan kegiatan gotong-royong, turun drastis.

Selain mengandung konsekuensi sosial, diskriminasi atas penyandang HIV/ AIDS juga berdampak ekonomi. Pada umumnya, penyandang HIV/AIDS sukar mendapatkan pekerjaan. Bahkan, setelah diketahui mengidap HIV/AIDS, sebagian mereka dipecat oleh para majikan mereka (Ramadhan, 2018; Ramadhani, 2019). Sementara itu, jika penyandang HIV/AIDS kebetulan adalah seorang pemilik usaha, para konsumen cenderung menghindari berbelanja di tempatnya. Dalam penelitian mereka, Herek et al. (2002) menemukan bahwa orang enggan membeli produk di toko-toko yang pemiliknya berstatus penyandang HIV/AIDS. Akibatnya, para penderita HIV/AIDS kesulitan mencari nafkah, justru ketika mereka membutuhkan uang untuk menutup banyak kebutuhan dan biaya rutin kesehatan mereka.

Beban fisik, sosial dan ekonomi dapat mengganggu kesejahteraan psikis para penyandang HIV/AIDS. Kewalahan menghadapi stres dan depresi, banyak penyandang HIV/AIDS sampai mencoba bunuh diri (Amalia, Sumartini, \& Sulastri, 2018). Di samping stres dan depresi, orang-orang juga mengalami aib, penyangkalan, frustrasi, kemarahan dan kecemasan setelah mengetahui mereka terinfeksi HIV/AIDS (Pardita \& Sudibia, 2014). Beban-beban psikologis ini sudah merundung mereka bahkan sebelum mereka menyingkapkan status diri sebagai penyandang HIV/AIDS kepada masyarakat.

Walaupun demikian, sampai derajat tertentu, para penyandang HIV/AIDS dapat hidup normal dan layak. Sebagai contoh, ada suami-istri penyandang HIV/AIDS yang berusaha menerima kondisi mereka, menjalani terapi, dan aktif mencari nafkah (Swastika \& Masykur, 2017). Selain dapat hidup secara normal, beberapa penyandang HIV/AIDS juga mampu menguasai keahlian baru dan berkontribusi positif kepada masyarakat. Ini adalah salah satu bukti empiris bahwa sebagian penyandang HIV/ AIDS telah berhasil meraih kesadaran transformatif, bangkit dari keterpurukan dan menguasai keterampilan baru untuk membantu orang-orang senasib. Prestasiprestasi tersebut dimungkinkan salah satunya karena ada dan bekerjanya "kreativitas tindakan" (Joas, 1996) pada penyandang HIV/AIDS tersebut. Kreativitas tindakan (creativity of action) ini mewujud dalam bagaimana mereka menyiasati pasangsurut perjalanan hidup pribadi (yang kadang mengejutkan) dan gejolak perubahan masyarakat (yang kadang membuat kewalahan). Upaya-upaya penyiasatan itu melibatkan adanya pemanfaatan rules dan resources dalam masyarakat, yaitu dua faktor yang disebut oleh Giddens (1984) sebagai "struktur".

Sejauh ini, pengalaman para penyandang HIV/AIDS umumnya dikaji dalam 
bidang psikologi melalui tema-tema seperti konsep diri, religiusitas dan kesejahteraan subjektif (Putra, 2016), serta dukungan sosial dan motivasi untuk bertahan hidup (Mahardining, 2010; Rahakbauw, 2016). Dalam upaya memahami transformasi positif pada diri ODHA (orang dengan HIV/ AIDS), para peneliti masih jarang menggunakan perjalanan hidup para ODHA itu (sebelum dan sesudah terinfeksi) dan dinamika psikologis mereka sebagai lensa analitis alternatif. Penelitian kami mencoba mengisi celah ini sebagai kontribusi bagi khazanah kajian psikologis tentang pengalaman psikis ODHA.

Penelitian ini menggunakan perspektif teori strukturasi Giddens yang menelaah interaksi antara agency seorang aktor sosial dengan daya-daya struktural dalam masyarakatnya. Interaksi ini berperan penting dalam produksi dan reproduksi praktikpraktik sosial (Giddens, 1984). Menurut Giddens (1984), melalui tindakan berulang manusia (sebagai aktor sosial) membangun praktik sosial. Giddens memakai istilah agency untuk merujuk pada kemampuan manusia melakukan berbagai tindakan sosial. Dalam masyarakat, struktur (yang terdiri dari rules dan resources) tidak hanya membatasi agency manusia, tetapi juga memberdayakannya. Karena itu, agency ikut memainkan peran penting dalam perubahan masyarakat (Lamsal, 2012).

Agency para penyandang HIV/AIDS (sebagai aktor sosial) berinteraksi dengan struktur yang bekerja dalam masyarakat mereka. Seperti diisyaratkan oleh Lamsal (2012), dengan mengerahkan agency-nya, seorang penyandang HIV/AIDS turut membangun struktur itu. Ini dilakukannya dengan berpartisipasi dalam penciptaan nilai-nilai dan norma-norma, serta dengan melakukan penerimaan sosial. Struktur berisi aturan-aturan (rules) dan berbagai sumber daya (resources), yang tersedia bagi dan dimanfaatkan oleh para penyandang HIV/AIDS dalam produksi dan reproduksi praktik-praktik sosial (Giddens, 1984). Dengan menuntut kepatuhan dari para penyandang HIV/AIDS dan menjatuhkan sanksi atas tindak-tindakan mereka, aturan-aturan turut mendukung sistem sosial (Lamsal, 2012). Di satu sisi, aturanaturan membatasi perilaku mereka. Di sisi lain, aturan-aturan memungkinkan mereka mengambil tindakan. Dengan kata lain, aturan-aturan memainkan tiga peran, yaitu: "konstitutif" (memungkinkan adanya tindakan), "interpretif" (memaknai tindakan), dan "preskriptif" (menetapkan bagaimana tindakan harus dilakukan).

Selain dibentuk oleh aturan-aturan, agency para penyandang HIV/AIDS juga dipengaruhi oleh berbagai sumber daya yang tersedia dalam masyarakat (Giddens, 1984). Melalui kehadiran dan ketidakhadirannya, melalui kuantitas dan kualitasnya, sumber daya tersebut dapat mendorong atau menghambat agency penyandang HIV/AIDS. Rumah sakit, lembaga pendidikan, pemerintahan kota, dan teknologi merupakan sumber daya yang dapat dimanfaatkan oleh penyandang HIV/AIDS untuk menjalankan agency mereka guna mencapai tujuan-tujuan hidup.

Menurut teori strukturasi, hubungan antara agency dan struktur pada kehidupan para penyandang HIV/AIDS berbentuk "dualitas". Artinya, keduanya bagaikan dua sisi dari sekeping uang logam, yaitu saling memengaruhi dan tak terpisahkan (Giddens, 1984). Dengan menjalankan agency-nya, penyandang HIV/AIDS dapat melestarikan dan mengubah struktur. Sementara itu, sebagai perangkat aturan dan sumber daya, struktur pun memengaruhi agency pada diri penyandang HIV/AIDS. Sebagai makhluk yang dapat menjalankan agency-nya, para penyandang HIV/AIDS berkemampuan melakukan produksi dan reproduksi masyarakatnya. Sampai batasbatas tertentu, mereka berkebebasan untuk bertindak secara selaras atau bertolak belakang dengan aturan-aturan dalam komunitasnya. Mereka bisa mengabaikan atau memanfaatkan berbagai sumber daya yang ada di sekeliling mereka.

Selain menggunakan teori strukturasi 
Giddens, penelitian ini juga menerapkan konsep agency Bandura (1999). Berdasarkan konsep agency Bandura, dapat dikatakan bahwa para penyandang HIV/AIDS akan menampilkan tiga kualitas dalam menjalani kehidupan mereka: efikasi diri (self-efficacy), representasi tujuan (goal representations), dan hasil yang diantisipasi (anticipated outcomes). Lebih khusus, agency merupakan produk dari interaksi timbal-balik antara tiga faktor: peristiwa dalam diri penyandang HIV/AIDS (kognitif, afektif dan biologis), pola perilakunya, dan peristiwa dalam lingkungannya (Bandura, 1999). Agency bukan sematamata produk mekanis dari kondisi sosial, sebab ia dibentuk juga oleh proses psikologis seorang penyandang HIV/AIDS ketika ia menjalankan agency-nya dalam bentuk tindakan-tindakan konkret. Perkembangan agency mereka dari waktu ke waktu dipengaruhi oleh pikiran, perasaan dan motivasinya. Seperti ditandaskan oleh Bandura (1989), hubungan antara agency dan lingkungan bersifat interaktif, yang satu memengaruhi yang lain.

Dalam studi ini, peneliti mengkaji sebagian dari perjalanan hidup Indah (nama samaran), seorang perempuan penyandang HIV/AIDS yang berhasil sembuh dari ketergantungan narkotika, psikotropika dan zat adiktif lainnya (NAPZA), tekun menjalani terapi HIV/ AIDS dan berhasil menjadi konselor adiksi. Studi ini mempelajari kekuatan dan keterbatasan agency Indah dalam menentukan orientasi dan kualitas kehidupnya. Studi ini juga ingin mengungkap dan memahami bagaimana agency Indah dibatasi dan diperkuat oleh daya-daya struktural.

\section{Metode}

Studi ini menggunakan metode quasilife history. Berbeda dengan metode life history yang mewajibkan peneliti untuk menyusun dan menafsirkan kisah hidup subjeknya secara menyeluruh, metode quasi-life history mengijinkan peneliti un- tuk mereka ulang dan menganalisis perjalanan hidup subjeknya secara parsial (Brantlinger et al., 2005). Guna mencapai tujuan itu, peneliti mengumpulkan dan mengolah data kualitatif berbentuk ingatan dan pandangan subjek tentang kejadiankejadian penting dalam hidupnya.

Ada dua alasan mengapa studi ini menggunakan quasi-life history. Pertama, subjek baru menjalani sebagian saja dari keseluruhan tahap-tahap perkembangannya. Kedua, kajian ini memang memusatkan perhatiannya hanya pada pengalamanpengalaman penting di masa dewasa subjek (Brantlinger et al., 2005; Nurchayati, 2010).

\section{Partisipan}

Partisipan utama penelitian ini adalah Indah, perempuan mantan pecandu yang adalah penyandang HIV/AIDS berusia 36 tahun yang sekarang bekerja sebagai konselor adiksi. Lahir di Surabaya pada 1985, Indah adalah anak bungsu dari tiga bersaudara. Sejak lahir, ia tinggal dengan kedua orang tuanya di Surabaya dalam rumah tangga yang berkecukupan. Ketika Indah beranjak remaja, kemacetan komunikasi dalam keluarga menyebabkan ia tidak betah di rumah. Ia merasa bahwa ayah dan ibunya membatasi kebebasannya dalam bergaul. Karena tidak tahan lagi menanggung kekangan seperti itu, Indah memberontak dari peraturan orang tua dan mencari berbagai kesenangan alternatif di luar rumah. Pemberontakan Indah ini berujung pada masalah dalam perjalanan hidupnya, yaitu ia menjadi pengguna dan pecandu NAPZA dan pengidap HIV/AIDS.

\section{Pengumpulan Data}

Data dikumpulkan menggunakan wawancara semi-terstruktur, yaitu wawancara yang mengacu pada pedoman pertanyaan dan garis-garis besar topik percakapan, namun tetap mengikuti alur pembicaraan subjek dengan mengajukan pertanyaan- 
pertanyaan tambahan untuk pendalaman data (Brouneus, 2011).

Untuk menjaga kualitas data, sebelum wawancara, peneliti telah membangun rapport dengan Indah. Relasi peneliti dengan Indah bermula pada hari ketika peneliti mengikuti acara capacity building, yang di dalamnya Indah bertindak sebagai pembicara. Sejak itu, kami terus berkomunikasi, antara lain melalui media sosial. Dalam percakapan-percakapan kami, Indah bukan hanya berbagi kabar, tetapi juga mengisahkan pengalamannya sebagai penyandang HIV/AIDS dan mantan pengguna NAPZA. Peneliti kemudian menawari Indah sebagai subjek penelitian dan ia menyatakan kesediaannya dengan menandatangani consent form. Wawancara tatap muka dilakukan dua kali pada 21 April dan 2 Mei 2020 dengan mematuhi protokol kesehatan COVID-19. Wawancara lanjutan dilakukan secara daring untuk mendalami data subjek.

\section{Analisis Data}

Analisis naratif digunakan dalam penelitian ini. Analisis tersebut dilakukan dengan cara peneliti mereka ulang peristiwa-peristiwa dalam riwayat hidup Indah dan menyusunnya secara tematis dan kronologis. Dengan menerapkan strategi berpikir kronologis (path dependency), peneliti menjelaskan rantai sebab-akibat dan menemukan makna-makna di balik perubahan diri Indah di sepanjang kurun waktu tertentu (Neuman, 2016). Hasilnya disajikan peneliti dalam bentuk narasi sistematis yang bermakna dan komunikatif (Wertz et al., 2011). Tujuan analisis naratif adalah membantu pembaca memahami secara intrinsik sebab-sebab, mekanisme, dampak dan makna transformasi kehidupan Indah. Peneliti mengungkapkan dinamika faktorfaktor yang mendasari transformasi Indah, bukan saja kondisi objektif masyarakat dan persepsi diri dan sosial Indah, tetapi juga tahapan, sebab, akibat, dan makna transformasi dirinya. Dalam analisis naratif ini, tidak dilakukan generalisasi empiris atau teoretis dari kasus Indah ke kasus-kasus serupa (Emerson \& Frosh, 2004).

\section{Hasil}

Hasil studi ini melaporkan transformasi subjek Indah dari pengguna dan pecandu NAPZA yang menyandang HIV/AIDS menjadi konselor adiksi. Transformasi ini disajikan dengan narasi analitis yang menonjolkan beberapa peristiwa kunci dalam perjalanan hidup Indah dan menunjukkan bahwa transformasinya itu adalah konsekuensi dari: a) interaksi antara agency Indah dan rules dan resources dalam masyarakatnya (sebagaimana diteorikan oleh Giddens); dan b) interaksi antara diri yang memiliki agency dengan lingkungannya (seperti pada konsep Bandura). Dalam narasi analitis ini, berbagai unsur penting dalam transformasi Indah dapat dilihat mulai dari sebab-sebab dan akibat-akibat sampai dengan tahap-tahap, konteks dan makna perubahan diri Indah.

\section{Menjadi Pecandu NAPZA}

Ada beberapa faktor yang mendorong Indah berubah menjadi pemakai NAPZA. Pada 1999, ketika masih duduk di bangku Sekolah Menengah Pertama, Indah mendapatkan uang saku yang lebih dari mencukupi. Namun, orang tuanya tidak membekalinya dengan kemampuan mengelola uang saku secara bijaksana. Sementara itu, mereka bersikeras membatasi pergaulan Indah, tanpa membekalinya dengan pedoman pergaulan sehat. Akibatnya, Indah terperosok ke pergaulan destruktif. Bersama dengan teman-teman sebaya yang salah arah, Indah berekreasi di dunia hiburan malam, mencuri, merokok, minum minuman keras, dan akhirnya mengonsumsi NAPZA. Mula-mula, Indah sekadar mencoba-coba. Ia mengatakan: "Sebenarnya [cuma] pingin mencoba". Namun, aksi coba-coba ini berdampak negatif. Ia menjadi begitu sering membolos sampai- 
sampai ia meninggalkan SMP tanpa ijazah. Selain itu, makin lama makin beragam pula NAPZA yang ia konsumsi, seperti psikotropika, ganja, metamfetamin, ekstasi dan "putaw" (fentanyl).

Sebenarnya, Indah sempat berhenti memakai NAPZA, yaitu ketika ia hamil dan melahirkan anak tunggalnya. Namun, setelah kematian anaknya dan perpisahan dengan suaminya, Indah kembali mengonsumsi NAPZA. Indah bertutur:

Aku mulai aktif lagi waktu suamiku meninggalkan aku [dan waktu] anakku ninggalin aku. Karena aku merasa kosong, nggak ada siapa-siapa lagi.

Peristiwa itu terjadi pada 2005. Indah terpuruk secara psikis setelah anaknya wafat dan sang suami meninggalkannya. Mereaksi keterpurukan itu, Indah kembali mengonsumsi NAPZA jenis putaw dan berbagi jarum suntik dengan sesama pengguna. Dengan cara itu, Indah mendapatkan kenyamanan, kenikmatan dan ketenangan semu. Ia akhirnya mengalami adiksi putaw. Adiksi ini menguat setelah seorang teman menjamin pasokan putaw untuknya. Indah memilih sebuah kuburan sepi di Surabaya sebagai tempat favorit untuk mengonsumsi putaw karena dia anggap paling aman.

Sebagai pecandu NAPZA, Indah tiga kali ditangkap polisi dan mendekam di bui: 2005, 2007 dan 2008. Pada 2005 dan 2007, ia mendekam sebentar di balik jeruji besi karena ia segera ditebus oleh kedua orang tua. Ironisnya, dalam bui Indah makin giat mengonsumsi NAPZA. NAPZA beredar bebas di lapas. Seperti terungkap dalam kesaksian Indah: "[Di] penjara sekarang [NAPZA] malah bebas peredarannya".

\section{Menjalani Rehabilitasi}

Atas prakarsa ayah dan ibunya, Indah menjalani dua kali rehabilitasi: setelah keluar dari bui pada 2005 dan 2007. Rehab pertama ditempuhnya di sebuah fasilitas di Madiun, sedangkan rehab kedua diikutinya di Balai Besar Rehabilitasi BNN Lido di
Bogor. Kedua program rehabilitasi ini gagal, karena Indah sendiri belum bertekad berhenti memakai NAPZA.

Indah baru berubah pada 2008, ketika ia masuk penjara lagi. Kali ini, Indah mohon agar ia tak ditebus oleh kedua orang tuanya. Ia memilih menjalani masa tahanan sampai selesai. Waktu itu, dalam diri Indah terbit kesadaran untuk memperbaiki hidupnya.

Akhirnya mulai jenuh. Maksudnya, masak sih aku seperti ini? Aku di dalam [penjara] nggak ada perubahan? Seenggaknya aku berpikir. Aku mulai ditawari lagi [tapi aku] sudah nggak [mau]. Kadang tak [ku] kasih ke temenku. Wis, ambilen [ambil saja]. Aku nggak mau. Di situ aku mulai lebih menjalani ibadah, doa terus, ikut persekutuan di aula.

Begitu masa tahanannya berakhir pada Maret 2009, dengan inisiatif sendiri, Indah menjalani program rehabilitasi di Pondok Pemulihan Doulos di Songgokerto, Batu. Tentang ini, ia bertutur:

Tapi [rehabilitasi] yang di Doulos itu memang aku sendiri yang meminta. Aku pingin benar-benar sembuh, nggak pakai lagi.

Doulos ia pilih karena lembaga ini berspirit Kristen Protestan. Dalam proses rehabilitasinya, Indah mencoba beberapa metode seperti substitusi obat dan "pasang badan". Dalam substitusi obat ini, subjek mengalihkan dorongan kuat mengonsumsi putaw dengan mengonsumsi methadone atau suboxone untuk menekan sakaw (rasa sakit akibat putus zat). Setelah tiga bulan, Indah menemukan bahwa metode substitusi obat ini tidak manjur. Adiksinya pasti kambuh lagi di kemudian hari. Indah pun beralih ke metode "pasang badan". Dalam metode ini, untuk mengeluarkan racunracun NAPZA, badan Indah disiram air dingin lalu direndam air panas di tengah malam selama 30 menit. Selama menjalani terapi ini, Indah masih kerap mengalami 
sakaw. Indah bercerita:

Ya sakit banget, tapi aku memang sudah berniat berhenti. Jadi, sering, kalau malam, aku nggak bisa tidur karena sakaw$\mathrm{ku}$ muncul. Sakit itu. Sampai badanku panas-dingin. Jadi menggigil panas tinggi, badan rasanya dingin banget. Sendisendiku linu semua. Tanganku seperti sudah lépoh [tak berdaya], nggak bisa bergerak.

Sekitar setahun Indah didera rasa sakit putus obat (sakaw). Namun, seiring waktu, sakaw berangsur-angsur menurun, sampai akhirnya lenyap total. Indah pun berhasil bebas dari adiksi NAPZA. Di malam Natal 24 Desember 2009, Indah resmi keluar dari Pondok Pemulihan Doulos karena telah dinyatakan sembuh.

\section{Menyandang HIV/AIDS}

Setelah bebas NAPZA, Indah menghadapi tantangan baru. Konsumsi NAPZA Indah di masa lalu membawa sebuah akibat yang tak diniatkannya (unintended consequence). Mula-mula, kesehatannya merosot tajam. Ia mudah terserang berbagai penyakit. Sakitnya pun tak kunjung sembuh. Ia sempat begitu frustrasi hingga mencoba bunuh diri:

Waktu masih bolak-balik ke Rumah Sakit Mitra Keluarga, aku pernah, [mencoba] bunuh diri [dengan] melompat dari lantai 5. Aku sudah putus asa. Aku ini sebenarnya sakit apa? Kok nggak ada titik terangnya?

Dokter akhirnya mendiagnosis Indah terinfeksi HIV/AIDS. Cara Indah mengonsumsi NAPZA dengan jarum suntik di masa silam menjadi penyebabnya:

Sekali lihat, profesor itu langsung tahu. Dia tanya, "Kamu dulu. sering ganti pasangan?" Aku jawab, "Nggak, Dok, tapi aku sering pakai jarum suntik gantiganti sama orang." Aku dites. Nah, baru tahu kalau aku positif HIV.
Indah resmi berstatus penyandang HIV/AIDS. Ayah dan ibunya mencari fasilitas kesehatan untuknya. Mereka memindahkannya ke sebuah rumah sakit nonrujukan yang bersedia merawat pasien HIV/AIDS secara terpisah dari pasien nonHIV/AIDS. Infeksi HIV/AIDS berdampak pada kesehatan Indah. Ia sempat koma dua bulan. Namun, ia berhasil sadar sebelum rumah sakit melucuti alat bantu napasnya karena orang tuanya kehabisan uang untuk ongkos perawatan. Dalam koma, Indah bermimpi bertemu dengan almarhum anaknya. Mimpi ini membantunya bangun dari koma. Setelah stabil, Indah pulang ke rumah.

Keluarga Indah berbagi tugas merawatnya. Selama ia diopname di rumah sakit, ayah dan ibunya mendampinginya. Kakak kedua Indah mencarikan rumah sakit yang aman baginya. Ia juga mengantarkan baju ganti untuk ayah dan ibu Indah. Berkat dukungan ayah, ibu dan kakak kedua, Indah bertahan menghadapi berbagai tantangan hidup sebagai penyandang HIV/AIDS.

Namun, sekeluar dari rumah sakit, Indah menghadapi tantangan baru sebagai penyandang HIV/AIDS: penolakan dari berbagai pihak. Andin, kakak pertamanya, menolak kehadirannya di rumah. Kedua orang tua Indah memohon para pengurus gereja mereka untuk memberikan tempat tinggal sementara bagi Indah. Permohonan ini ditolak. Akhirnya, sebuah masjid dekat rumah Indah memberi tempat bernaung. Secara perlahan Andin mulai luluh karena upaya orang tuanya. Ia menerima Indah pulang dengan syarat Indah memakai peralatan makan sendiri dan tidak menggunakan fasilitas bersama. Indah menerima perlakuan itu dan memandangnya sebagai konsekuensi dari tindakannya di masa lalu.

Perlakuan dibedakan di dalam rumahnya karena ia menderita HIV/AIDS membawa dua akibat. Pertama, Indah takut ditolak pasangan dan masyarakat yang memandangnya berpotensi untuk menularkan HIV/AIDS. Kedua, ia khawatir statusnya 
sebagai penyandang HIV/AIDS menyebabkan keluarganya menanggung dampak negatif. Kondisi ini membuat Indah takut bertemu dengan orang lain:

Waktu aku positif HIV dan bertemu kembali dengan kakakku, [dia] benar-benar menolak aku. Itu [membuat] aku down. Sampai-sampai nggak ingin berinteraksi sama orang-orang. Takutnya, kalau mereka tahu aku positif, mereka akan menjauh. Makanya, setelah aku tahu positif, aku nggak punya banyak teman.

Selain khawatir bisa menulari orang lain, Indah juga takut ditolak oleh calon pasangan:

Kadang aku takut cari pasangan. Meskipun ada, bisa nggak dia menerima aku kalau tahu aku positif? Itu sempat dilema. Aku pernah ditolak beberapa kali sama cowok [begitu] aku ngomong aku positif HIV. Akhirnya, itu jadi ketakutanku juga.

Indah juga khawatir jika orang-orang terdekatnya turut menanggung dampak dari penyakitnya. Indah takut jika ketahuan dirinya menderita HIV/AIDS, tetangga akan memperlakukan keluarganya dengan buruk. Itu sebabnya Indah berusaha menyembunyikan penyakitnya dengan cara berganti-ganti apotek dalam membeli obat, dan berpindah-pindah klinik dalam menjalani pengobatan. Kekhawatiran Indah ini bisa dimengerti karena pandangan dan perlakuan negatif terhadap penyandang HIV/AIDS dan pecandu NAPZA masih terjadi di masyarakat. Indah mengetahui hal tersebut dan menunjukkan responnya:

Aku nggak menyetujui [anggapan] bahwa semua pengguna narkoba itu bodoh, jahat, kriminal. Nggak semua seperti itu. Itu [tergantung] pembawaan orangnya. Sama halnya dengan penderita HIV. Dulu, sebelum ada sosialisasi HIV/AIDS, image penderita HIV/AIDS jelek: pelacurlah, gonta-ganti pasanganlah.

Untuk melawan stigma tersebut, Indah tak henti memperbaiki diri. Ia ingin membuktikan bahwa ia bisa menjadi lebih baik. Sebagai penyandang HIV/AIDS dan mantan pencandu NAPZA, Indah terbukti berhasil bangkit dari keterpurukan. Orangorang yang dulu meremehkannya kini ikut membanggakan perubahan positifnya:

Dulu aku [punya] image jelek di kampung. Sekarang, mereka bangga lho sama aku. Itu setelah aku diajak CNN dan SCTV untuk shooting di kampungku.

Meski sempat diperlakukan buruk oleh sebagian warga masyarakat, Indah tabah menghadapi. Akhirnya ia bertransformasi menjadi sosok positif, yang layak dibanggakan mereka yang mengenalnya.

Penerimaan masyarakat sekitar atas dirinya mendorong Indah untuk mulai memikirkan orang-orang yang senasib dengannya. Penyandang HIV/AIDS mendapatkan bantuan dari berbagai lembaga pemerintah maupun swasta. Bantuan itu berbentuk obat-obatan, vitamin, uang dan pelatihan. Namun, dalam berapa kasus, ada indikasi perlakuan diskriminatif. Bantuan didistribusikan tidak merata berdasarkan latar belakang penyandang HIV/AIDS. Indah melaporkan bahwa para penyandang HIV/AIDS yang berlatar belakang pecandu NAPZA kurang dipedulikan:

Los losan [dibiarkan], nggak terlalu [dipedulikan]. Ya masih seperti ini: "Ini "kan [akibat] ulahmu [sendiri]." Para penyandang [HIV/AIDS] berlatar belakang ibu rumah tangga menjadi pantauan.

Sambil menjalani pengobatannya sendiri, Indah membantu sesama penyandang HIV/AIDS. Ia menebuskan obat mereka di Rumah Sakit dan mengantarkan obat itu ke rumah mereka. Dengan membantu sesama, Indah merasa hidupnya bermanfaat dan mendapat kekuatan untuk menerima diri.

\section{Menjadi Konselor Adiksi}

Pada suatu hari Indah bertemu dengan 
staf dari Yayasan Orbit, sebuah Lembaga Sosial Masyarakat (LSM) yang berfokus pada rehabilitasi pecandu NAPZA. Tak lama kemudian, Indah bergabung dengan Yayasan Orbit dengan bekerja sebagai Pendamping Lapangan (PL) untuk para pecandu putaw di jalanan. Setelah masa tugasnya sebagai PL selesai, Indah selanjutnya menapaki karir sebagai konselor adiksi. Yayasan Orbit berperan penting dalam perubahan Indah dalam hidupnya. Pertama, Yayasan Orbit membantu Indah menerima dirinya sebagai penyandang HIV/AIDS dan memulihkan rasa percaya dirinya. Rasa percaya diri Indah pulih setelah ia menjalani kegiatan-kegiatan pendampingan bersama lembaga tersebut.

Orang-orang di Orbit membuat aku bisa benar-benar merasa aku itu nggak sendiri. [Mereka berkata]: "Jadi, bukan hanya kamu yang ODHA; kita semua ini juga sama seperti kamu".

Kedua, Yayasan Orbit membantu Indah membangun kembali hidupnya dengan memberinya kesempatan kerja sebagai konselor adiksi, yang bertugas mendampingi rehabilitasi para pecandu NAPZA. Indah melihat pekerjaannya sesuai dengan latarbelakangnya. Dalam melaksanakan tugas ia dapat memanfaatkan modalnya: pengalaman hidupnya sebagai pecandu dan pasien rehabilitasi pecandu NAPZA, serta sebagai penyandang HIV/AIDS karena jarum suntik.

Indah memulai karirnya sebagai konselor adiksi tanpa bekal pendidikan formal. Indah harus lebih dulu menguasai unsurunsur teknis pekerjaan sebagai konselor. Dalam pembelajarannya, Indah mendapatkan pendampingan:

Jadi, [aku] belajar lagi. Banyak yang harus dipelajari: tata-caranya bertemu langsung dengan klien. [...] Aku [ikut] training hampir enam bulan. Terus, mulai aktif, sering [memberikan] konseling. Akhirnya, terbiasa.
Profesi konselor adiksi menuntut Indah beradaptasi. Pertama, sebagai orang yang mengaku ekstrovert, Indah menghadapi beberapa masalah, di antaranya, ia tak membatasi relasinya dengan klien. Pada taraf tertentu ia dituntut untuk mengambil jarak demi kebaikan klien. Kedua, Indah merasa belum kompeten sebab ia sendiri belum total dalam mengamalkan saran-saran yang diberikannya pada para klien. Indah melakukan berbagai upaya untuk mengatasi persoalan-persoalan ini. Pertama, ia membahas masalah-masalah yang dihadapinya dengan para rekan kerja:

Kita harus bisa cerita ke siapa pun yang benar-benar kita percayai. Walau nggak ada jalan keluar yang murni, kita bisa merasa lega. Paling nggak, beban dalam pikiran kita [berkurang].

Kedua, Indah menerapkan saran-saran positif yang diterimanya. Ketiga, ia melakukan katarsis. Ia mencurahkan emosinya dalam berbagi pengalaman di forum-forum obrolan daring, seperti Facebook. Keempat, ketika belum tenang menghadapi masalah, ia memilih tidur. Sejauh ini, caracara tersebut cukup ampuh membantunya menghadapi berbagai tantangan sebagai konselor adiksi.

Lebih khusus, ada dua cara Indah dalam berbagi pengalaman dan tantangan. Pertama, ia menuturkan masalah-masalahnya kepada teman. Dengan begitu, Indah memperoleh bantuan untuk menemukan cara-cara pemecahan masalah. Di samping itu, Indah lega karena ada orang lain yang bersedia mendengarkannya dan menerima kondisinya. Tambahan lagi, Indah makin mampu menerima dirinya sendiri, tak lagi dilanda emosi negatif setiap kali ada orang menemukan statusnya sebagai penyandang HIV/AIDS. Indah mengingat motivasi yang ia terima dari teman-temannya:

Percaya diri. Jangan anggap penderita HIV itu akan dikucilkan oleh banyak orang. Jangan kamu menutup diri dari orang lain." 
Indah berharap agar pengalamannya yang pernah menjadi pecandu NAPZA hingga saat ini harus menyandang HIV/AIDS, dapat menjadi bahan pembelajaran bagi orang lain:

Aku ambil sisi positifnya saja. Yang penting, aku berbagi sama mereka. Intinya, jangan sampai mereka melakukan apa yang aku lakukan. Itu saja. Aku jadi mulai berani bertestimoni bahwa aku ini positif HIV.

Temuan ini menandakan adanya beberapa aktor sosial yang berperan besar dalam membantu Indah menerima dirinya kembali dan memulihkan rasa percaya diri sebagai penyandang HIV/AIDS.

Indah telah menerima kondisinya sebagai penyandang HIV/AIDS. Ia tabah menghadapi pandangan-pandangan orang lain tentang statusnya itu. Hidupnya pun telah bertransformasi sedemikian rupa sehingga ia mampu berkontribusi pada masyarakat sebagai konselor adiksi. Ia bahkan berencana punya anak. Dengan menerima diri sendiri, serta memaknai hidupnya secara konstruktif, ia mempertahankan keseimbangan diri dalam menghadapi bermacam komentar, pemikiran, penilaian dan perlakuan masyarakat pada dirinya. Indah telah menumbuhkan kemampuan memberikan respons positif. Indah bisa menerima bahwa masyarakat berhak berpikir dan berpendapat. Dengan demikian, Indah dapat menjaga hubungan baik dengan diri sendiri dan dunia luar.

Hidup sebagai seorang penyandang HIV/AIDS berarti menghadapi berbagai tantangan, baik dari dalam diri maupun dari masyarakat. Corak, proses dan dampak dari kehidupan sebagai penyandang HIV/AIDS ditentukan oleh cara penyandang HIV/AIDS itu mengolah tantangan dan memecahkan masalah. Dalam kasus Indah, ia menanggulangi tantangan hidupnya dengan meminta dan menerima dukungan dari sesama manusia. Dengan begitu, ia dapat memperbaiki kelemahan, melampaui keterbatasannya, dan meningkatkan ketangguhan dirinya. Dengan menggabungkan upaya diri sendiri dan dukungan sosial, Indah menemukan jalan menuju transformasi positif dalam hidupnya, yaitu menjadi konselor adiksi.

\section{Pembahasan}

Secara keseluruhan, temuan-temuan riset ini, seperti telah dipaparkan di atas, meneguhkan salah satu klaim utama teori strukturasi, yaitu bahwa praktik sosial (misalnya konsumsi NAPZA dan ditekuninya profesi sebagai konselor adiksi) diproduksi dan direproduksi oleh interaksi antara agency seorang aktor sosial dan struktur dalam masyarakatnya (Giddens, 1984). Agency Indah terwujud dalam kapasitasnya untuk bertindak, sedangkan struktur (yang berupa aturan dan sumber daya) dimanfaatkan oleh Indah dalam produksi dan reproduksi tiga perilakunya: konsumsi NAPZA, pembebasan diri dari NAPZA, dan transformasi menjadi konselor adiksi (Giddens, 1984).

Dalam ketiga perilaku tersebut di atas, struktur dan agency tampak saling mempengaruhi: struktur mempengaruhi caracara Indah menanggapi lingkungannya. Sebaliknya, agency Indah turut mengubah struktur yang ada dalam masyarakatnya. Indah mengekspresikan agency-nya dalam berbagai pikiran dan tindakan. Ketika menanggapi berbagai peristiwa hidupnya, Indah menjalankan agency-nya dengan berbagai cara. Sebagai contoh, merasa tertekan di rumah, ia mencari kenyamanan alternatif di luar rumah. Begitu sadar bahwa dirinya hamil, ia berhenti mengonsumsi narkoba. Ketika secara bersamaan ia ditinggal pergi suami dan ditinggal mati anaknya, Indah kembali menggunakan NAPZA.

Pembahasan atas hubungan timbalbalik dalam perjalanan hidup Indah antara agency dan struktur diulas lebih lanjut dalam beberapa tema kunci berikut. 
Agency dan Unintended Consequences di Masa Remaja

Tahap perkembangan aktor sosial menentukan kemampuan mereka dalam menjalankan agency. Sebagaimana dicatat oleh Crockett (2002), para remaja sudah mulai mampu menentukan tujuan, menyusun rencana dan bertindak. Mereka mulai mengevaluasi dunia mereka dan jika menemui tantangan, mereka sudah berani menanggapinya melalui tindakan konkret. Ini terjadi pada Indah ketika memasuki tahap perkembangan remaja. Waktu itu ia merasa peraturan-peraturan orang tuanya mengganggu gugat kebebasannya. Dalam menyikapi persoalan ini, Indah menjalankan agency-nya dengan memberontak pada otoritas orang tua. Ia mencari lingkungan sosial alternatif, yang ia anggap mengukuhkan kebebasannya, yaitu teman-teman sebaya yang ternyata pengguna NAPZA.

Kelabilan emosi para remaja merusak kejernihan berpikir mereka. Dalam sebagian kasus, penalaran yang tidak jernih (sebagai pelaksanaan agency) dapat membuahkan apa yang disebut Giddens (1984) sebagai "unintended consequences", misalnya terjerumusnya remaja dalam perilaku destruktif yang kelak mereka sesalkan sendiri. Pada kasus Indah, rasa terkekang dan rasa tidak dipahami oleh orang tua membuat Indah mendambakan kehidupan alternatif di mana ia bebas bergaul dengan siapa pun dan berbuat apa saja. Dalam menanggapi situasi ini, Indah menjalankan agency-nya dengan berbuat sesuka hati dan melakukan berbagai tindakan yang bertentangan dengan peraturan ayah dan ibu. Seperti sudah lama ditemukan oleh Markus dan Nurius (1986), pelaksanaan agency di kalangan remaja berbentuk antara lain penetapan tujuan, penyusunan makna dan pembuktian nilai-nilai pribadi mereka pada masyarakat. Tak heran, sebagai remaja Indah menilai tinggi otonominya sebagai pribadi. Secara sempit, ia memaknai peraturan orang tuanya sebagai kekuatan negatif yang mengganggu otonominya.
Lalu, ia mengejar tujuan, yaitu membela otonominya dengan melarikan diri ke lingkaran sosial yang dibayangkannya lebih kondusif daripada rumahnya sendiri.

Menurut teori strukturasi, pelaksanaan agency akan menghasilkan "konsekuensi reguler" (regularized consequences) dan "konsekuensi yang tidak diniatkan" (unintended consequences) (Giddens, 1984). Dalam cukup banyak kasus, unintended consequences muncul karena aktor sosial tidak memiliki kapasitas memadai untuk menanggapi persoalan. Dalam kasus Indah di masa remaja, ia menanggung beberapa unintended consequences dari cara-cara menjalankan agency yang tidak memadai, yaitu meniru pola perilaku destruktif teman-teman sebaya, menerjuni hiburan malam sebagai gaya hidup, merokok, minum minuman keras, dan mengonsumsi NAPZA. Tindak agency seperti ini memunculkan unintended consequences yang destruktif, yaitu: adiksi NAPZA dan infeksi HIV/AIDS. Dalam jangka panjang, adiksi menggerogoti otonominya dengan menjadikannya budak putaw. Padahal, niat Indah memberontak pada peraturan orang tua adalah untuk melindungi otonominya. Sekarang NAPZA justru menghancurkan otonomi itu. Tambahan lagi, ketidakmampuan Indah dalam menjalankan agency mendatangkan unintended consequence yang jauh lebih merusak. Akibat berbagi jarum suntik dengan teman-temannya ketika mengonsumsi NAPZA, Indah terinfeksi HIV/AIDS. Penelitian ini mengungkap bahwa di masa remajanya Indah sudah berkemampuan menjalankan kehendak-kehendaknya sendiri. Akan tetapi, ia belum dapat mengendalikan kemampuan itu dengan pertimbangan rasional atas akibat-akibat (positif dan negatif serta jangka pendek dan jangka panjang) dari berbagai alternatif tindakan.

\section{Dampak Struktur atas Agency}

Selain dipengaruhi oleh tahap perkembangan manusia dalam rentang kehi- 
dupan, agency juga dipengaruhi oleh struktur dalam masyarakat tempat aktor sosial bermukim. Seperti tampak dalam perjalanan hidup Indah, struktur dapat memberdayakan sekaligus menghambat agency (Giddens 1984).

Sebagai dua perwujudan dari struktur, baik aturan maupun sumber daya bervariasi dari satu komunitas ke komunitas lain. Seperti dicatat oleh Oppong (2014), variasi tersebut mempengaruhi bagaimana aktor sosial menjalankan agency-nya. Sebagai komunitas yang disfungsional atau destruktif, teman-teman sebaya Indah memiliki aturan dan sumber daya yang mendorongnya untuk mengamalkan agency secara disfungsional atau destruktif pula.

Hal serupa terjadi dalam keluarga Indah. Di masa remajanya, aturan-aturan yang serba mengekang, interaksi minimalis dan kemacetan komunikasi dalam keluarga mendorongnya untuk berontak secara kontraproduktif: bergabung dengan komunitas remaja yang destruktif. Ketidakbijaksanaan orang tua Indah dalam menggunakan sumber daya keuangan berperan juga dalam melestarikan perilaku Indah sebagai pecandu NAPZA. Dengan dua kali menebus Indah dari penjara, ayah dan ibu Indah menghambat munculnya efek jera pada diri anak mereka.

Seperti dikemukakan Hurlock (2011), salah satu faktor yang menciptakan keluarga disfungsional adalah konflik antara orang tua dan remaja tentang norma sosial. Di masa remaja Indah, kesenjangan antargenerasi ini memicu konflik antara dirinya dan kedua orang tua. Gagalnya kedua belah pihak mencapai konsensus tentang aturan pergaulan adalah salah satu faktor yang memotivasi Indah untuk bergabung dengan komunitas para remaja pengguna NAPZA. Menurut Hurlock (2011), kesenjangan dan konflik antara orang tua dan anak remaja dapat dipecahkan dengan tiga langkah: ayah dan ibu mencoba memahami aspirasi anak; orang tua bersabar menerima kegagalan anak; dan kedua belah pihak ber upaya untuk membangun komunikasi yang efektif (Hurlock, 2011).

\section{Perilaku Selektif sebagai Ekspresi Agency}

Berbeda dengan kenyataan hidup Indah di masa remaja, jika orang hidup dalam sebuah komunitas yang berstruktur kondusif, maka dia pun akan terdorong untuk melaksanakan agency-nya secara sehat (Giddens, 1984; Oppong, 2014). Ini karena aktor sosial, seperti dikemukakan oleh Bandura (1977), berkapasitas untuk menciptakan lingkungannya sendiri secara aktif. Ia bisa memodifikasi lingkungannya dengan menyeleksi peristiwa-peristiwa mana saja di dalamnya untuk ia ikuti, intervensi, koordinasikan dan tindak lanjuti. Dengan mengabaikan stimulus-stimulus destruktif, seorang aktor sosial akan lebih mampu untuk menindaklanjuti berbagai stimulus konstruktif.

Argumen teoretis Bandura di atas diteguhkan oleh Elder dan O'Rand (1995) yang mengamati bahwa dalam hidupnya, manusia memilih untuk mengadopsi unsurunsur dalam dunianya yang dianggapnya sesuai dengan pengalaman di masa lalu dan dengan tendensi-tendensi kepribadiannya. Artinya, kalau mau, seorang aktor sosial bisa memilih satu dari dua alternatif ini, yaitu: sepenuhnya mengikuti arus lingkungan, termasuk pola perilaku destruktif, atau memilih pengaruh-pengaruh positif saja. Pada masa dewasanya, Indah mengevaluasi berbagai stimulus yang dijumpainya di Surabaya dan memilih menindaklanjuti berbagai stimulus positif. Setelah menjalankan agency-nya dengan berpedoman pada strategi ini, Indah berhasil memperbaiki hidupnya. Komunikasinya dengan orang tua dan saudara-saudara menjadi efektif. Ia juga berprofesi sebagai konselor adiksi di Yayasan Orbit, tempat ia memperoleh dukungan sosial dari rekan-rekan dan mentor. Dengan dukungan struktur seperti ini, Indah berhasil menerima dirinya sebagai penyandang HIV/AIDS. Kesimpulannya, jika direspons secara strategis, maka struktur dalam komunitas dapat memberdayakan aktor sosial untuk 
menjalankan agency secara produktif. Menurut Larson (2000), sebagai hasil pembelajaran, agency dipengaruhi oleh komunitas tempat aktor sosial bermukim. Aturanaturan yang berlaku dalam komunitasnya turut membentuk perilaku aktor sosial, baik sebagai penghambat maupun sebagai pendukung agency-nya (Giddens, 1984).

Selain dipengaruhi oleh struktur, agency juga mempengaruhi struktur. $\mathrm{Hu}-$ bungan timbal-balik ini disebut "dualitas" oleh Giddens (1984). Bekerjanya dualitas antara struktur dan agency kita temukan ketika struktur yang tersedia di Yayasan Orbit membantu Indah menjalankan peran agency-nya dengan menjadi konselor adiksi, sebuah profesi yang berkontribusi positif pada masyarakat. Ini dilakukan Indah dengan memanfaatkan modalnya, yaitu pengalamannya sebagai penyandang HIV/ AIDS dan mantan pengguna NAPZA. Transformasi Indah ini membenarkan pendapat Lamsal (2012) bahwa aktor sosial berpartisipasi dalam pembentukan struktur dalam masyarakat, yaitu dengan menciptakan nilai-nilai dan norma-norma serta menguatkan penerimaan sosial. Cara Indah memainkan agency-nya turut membantah beberapa prasangka negatif yang berkembang dalam masyarakat tentang para pecandu NAPZA dan penyandang HIV/ AIDS.

\section{Proses-proses Psikis dalam Agency Pengguna NAPZA}

Bandura (1989) berpendapat bahwa cara aktor sosial melaksanakan agency dipengaruhi oleh proses psikologis, yang mencakup, antara lain, kognisi, afeksi dan motivasi. Lebih jauh, Bandura berteori bahwa agency timbul dalam tiga cara. Cara pertama adalah "representasi tujuan" (goal representations). Dalam proses ini, aktor sosial memaksimalkan peluang mencapai hasil positif dengan menyusun sebuah rencana tindakan, yang berisikan antisipasi tentang konsekuensi tindakan tersebut (Bandura, 1989). Gagasan ini disetujui oleh Heckhausen, Wrosch, and Schulz (2018). Mereka menyatakan bahwa ketika aktor sosial menjalankan agency, tindakan itu mengejar sebuah tujuan dan didorong oleh harapan untuk sukses.

Untuk menuangkan agency dalam bentuk usaha mencapai tujuan, aktor sosial membutuhkan motivasi intrinsik (Larson, 2000). Sementara itu, baik positif maupun negatif, sebuah konsekuensi yang berada terlalu jauh di masa depan tidak punya kekuatan besar untuk memotivasi aktor sosial di masa sekarang (Bandura, 1989). Ini karena konsekuensi yang terlalu berjangka panjang belum punya dampak langsung atas diri aktor sosial di masa sekarang. Padahal, dampak langsung di masa kini adalah motivator kuat bagi aktor sosial untuk bertindak. Artinya, yang memotivasi Indah untuk melaksanakan agency dengan mengonsumsi NAPZA adalah dorongan di masa remaja untuk melarikan diri dari kungkungan orang tua dan mencari kebebasan di luar rumah. Demikian pula, tindakan Indah memerankan agency dengan menjalani rehabilitasi adalah buah dari dorongan di waktu itu untuk membebaskan diri dari derita fisik dan psikis akibat adiksi NAPZA. Jadi, kondisi afektif yang tengah dialami Indah mendorongnya memerankan agency, yaitu dengan mengonsumsi NAPZA di masa remaja dan dengan mengikuti rehabilitasi di masa dewasa awal. Kondisi afektif ini mendorong Indah menetapkan tujuan. Pada masa remaja, tujuan itu adalah kesenangan dan kebebasan tanpa pikir panjang. Pada masa dewasa awal, tujuan itu adalah kemerdekaan dari derita ketergantungan NAPZA.

Selain dipengaruhi oleh motivasi, pencapaian tujuan dipengaruhi juga oleh umpan balik (Bandura, 1989). Dalam rangka mencapai tujuan, umpan balik yang diterima aktor sosial setelah melakukan tindakan pertama dapat membentuk tindakan dia yang kedua, dan seterusnya. Guna melepaskan diri dari adiksi NAPZA, Indah menempuh rehabilitasi. Pada suatu titik 
dalam kehidupan Indah, ia berusaha berhenti mengonsumsi NAPZA. Tindakan ini memperoleh umpan balik dari kedua orang tua, yaitu dukungan moril dan material. Lalu, umpan balik ini ikut membentuk tindakan Indah berikutnya, yaitu menjalani program rehabilitasi NAPZA. Ryckman (1997) berpendapat bahwa baik positif maupun negatif, umpan balik atas tindakan aktor sosial mempengaruhi pikiran dan tindakannya. Contohnya, umpan balik positif dari ayah, ibu, dan saudara kandung memperkuat upaya-upaya Indah di panti rehabilitasi dalam mengatasi tantangan menuju kesembuhan. Akhirnya, Indah berhasil membebaskan diri dari adiksi NAPZA.

Menurut Bandura (1989), pencapaian tujuan juga dipengaruhi oleh faktor intraindividual, yaitu persepsi aktor sosial tentang efikasi dirinya. Menurut Colman (2006), efikasi diri adalah kemampuan aktor sosial dalam mencapai hasil yang dikehendakinya. Dengan efikasi diri yang kuat, aktor sosial berupaya meraih tujuan dengan menembus tantangan yang lebih berat, bertahan lebih lama ketika dihadang oleh kesulitan dan berjuang semaksimal mungkin (Bandura, 1989). Dalam proses rehabilitasi, Indah menanggung rasa sakit luar biasa dalam tubuhnya akibat putus zat (sakaw). Efikasi diri membantu Indah tabah melewati sakaw. Artinya, efikasi diri berperan penting membantu Indah untuk konsisten menjalankan agency-nya secara positif (Johnston, Brezina, \& Crank, 2019). Indah lalu mampu melewati masa sakaw dan meraih sukses dalam rehabilitasi.

Untuk menutup bagian pembahasan ini, perlu dikemukakan sebuah refleksi teoretis bahwa agency dan struktur bekerja secara terpadu (seperti dwitunggal) dalam produksi dan reproduksi praktik-praktik sosial. Sebagai penyandang HIV/AIDS, Indah melaksanakan agency sesuai dengan kapasitasnya dalam memecahkan masalah dan beraktualisasi diri, sampai ia mampu berkontribusi positif pada masyarakat, yaitu dengan membantu menanggulangi penyalahgunaan NAPZA. Dalam wujud- nya sebagai aturan-aturan dan sumbersumber daya, struktur yang dijumpai Indah dalam komunitasnya mempengaruhi cara dia melaksanakan agency sebagai penyandang HIV/AIDS, pencandu NAPZA dan, akhirnya, konselor adiksi. Agency tidak hanya dipengaruhi oleh struktur, tetapi juga oleh proses-proses psikologis dalam diri aktor sosial.

\section{Simpulan}

Penelitian ini menemukan bahwa dalam perjalanan hidup Indah, infeksi HIV/ AIDS dan ketergantungan pada NAPZA adalah konsekuensi yang tidak dimaksudkan (unintended consequences) dari caracaranya dalam menjalankan agency pada masa remaja. Sampai derajat tertentu, caracara tersebut dipengaruhi oleh interaksi Indah dengan struktur, baik dalam keluarga inti maupun dalam komunitas teman sebayanya.

Selain dapat menghambat agency Indah, struktur dapat pula memberdayakan agency-nya, seperti misalnya mendorongnya untuk memutuskan berhenti mengonsumsi NAPZA secara total dan bahkan kemudian menjalani karir sebagai konselor adiksi. Dengan menjalankan agency-nya secara konstruktif, Indah telah membantah stigma yang ditempelkan sebagian masyarakat pada para penyandang HIV/AIDS.

Perjalanan hidup Indah berkaitan erat dengan pergulatannya dengan berbagai masalah dan dampak emosional yang diakibatkannya. Untuk memecahkan berbagai masalah itu, Indah melakukan perumusan tujuan, yaitu bebas dari NAPZA, bertahan hidup sebagai penyandang HIV/ AIDS, dan melakukan aktualisasi diri sebagai konselor adiksi.

\section{Saran}

Penelitian ini adalah tentang seorang perempuan muda penyandang HIV/AIDS dan mantan pencandu NAPZA. Salah satu aspek yang belum tergali dan dibahas oleh 
studi ini adalah faktor gender. Untuk meningkatkan pemahaman psikologis atas dinamika struktur dan agency dalam perjalanan hidup perempuan yang berinteraksi dengan NAPZA dan menyandang HIV/ AIDS, peneliti menyarankan agar studistudi berikut memusatkan perhatiannya pada aspek gender. Di samping itu, para peneliti berikutnya dapat mengkaji pula aktor-aktor penting lain dalam bidang NAPZA dan HIV/AIDS, seperti pengelola panti rehabilitasi, administrator penjara, polisi antinarkotika, gereja, pesantren, klinik, dan lain-lain. Dengan demikian, akan tercapai sebuah gambaran yang lebih komprehensif tentang dinamika yang bekerja dalam dunia NAPZA dan HIV/ AIDS.

\section{Daftar Pustaka}

Amalia, R., Sumartini, S., \& Sulastri, A. (2018). Gambaran perubahan psikososial dan sistem pendukung pada orang dengan HIV/AIDS di Rumah Cemara Gegerkalong Bandung. Jurnal Pendidikan Keperawatan Indonesia, 4, 77-85. https://doi.org/10.17509/jpki.v4i1.12 346

Bandura, A. (1977). Social learning theory. New Jersey: Prentice-Hall.

Bandura, A. (1989). Human agency in social cognitive theory. American Psychologist, 44, 1175-1184. https://doi.org/10.1037/0003066X.44.9.1175

Bandura, A. (1999). Social cognitive theory: An agentic perspective. Asian Journal of Social Psychology, 2, 2141. https://doi.org/10.1111/1467839X.00024

Brantlinger, E., Jimenez, R., Klingner, J., Pugach, M., \& Richardson, V. (2005). Qualitative studies in special education. Exceptional Children, 71, 195-207.

https://doi.org/10.1177/00144029050 7100205

Brouneus, K. (2011). In-depth interviewing: The process, skill and ethics of interviews in peace research. In K. Höglund \& M. Öberg (Eds.), Understanding peace research: Methods and challenges (pp. 130-145). London: Routledge.

Colman, A. M. (2006). Oxford dictionary of psychology. Oxford: Oxford University Press.

Crockett, L. J. (2002). Agency in the life course: Concepts and processes. In R. Dientsbier \& L. J. Crockett (Eds.), Agency, motivation, and the life course (pp. 1-30). Nebraska: The University of Nebraska Press.

Elder, G.H., \& O'Rand, A.M. (1995). Adult lives in a changing society. In K. S. Cook, G.A. Fine, \& J.S. House (Eds.), Sociological perspectives on social psychology (pp. 452-475). Boston: Allyn and Bacon.

Emerson, P., \& Frosh, S. (2004). Critical narrative analysis in psychology a guide to practic. London: Palgrave Mcmillan.

Giddens, A. (1984). The constitution of society. Cambridge: Polity Press.

Heckhausen, J., Wrosch, C., \& Schulz, R. (2018). Agency and motivation in adulthood and old age. Annual Review of Psychology, 70, 191-217. https://doi.org/10.1146/annurevpsych-010418-103043

Herek, G. M., Capitanio, J. P., \& Widaman, K. F. (2002). HIV-related stigma and knowledge in the United States: Prevalence and trends, 1991- 
1999. American Journal of Public Health, $\quad 92, \quad 371-377$. doi:10.2105/ajph.92.3.371

Hurlock, E. B. (2011). Psikologi perkembangan: Suatu pendekatan sepanjang rentang kehidupan. Jakarta: Penerbit Erlangga.

Joas, H. (1996). The creativity of action. Cambridge: Polity Press.

Johnston, T. M., Brezina, T., \& Crank, B. R. (2019). Agency, self-efficacy, and desistance from crime: An Application of social cognitive theory. Journal of Developmental and Life-Course Criminology, 5, 6085. https://doi.org/10.1007/s40865018-0101-1

Kementerian Kesehatan RI (Kemenkes RI). (2018). Situasi umum HIV/AIDS dan tes HIV. Retrieved from https://pusdatin.kemkes.go.id/article/ view/19042200004/situasi-umumhiv-aids-dan-tes-hiv.html

Lamsal, M. (2012). The structuration approach of Anthony Giddens. Himalayan Journal of Sociology \& Antropology, 5, 111-122. https://doi.org/10.3126/hjsa.v5i0.704 3

Larson, R. W. (2000). Toward a psychology of positive youth development. American Psychologist, $\quad$ 55, 170-183. https://doi.org/10.1037//0003066X,55.1.170

Mahardining, A. B. (2010). Hubungan antara pengetahuan, motivasi, dan dukungan keluarga dengan kebutuhan terapi ARV ODHA. Jurnal Kesehatan Masyarakat, 5, 131-137.

https://doi.org/10.15294/kemas.v5i2. 1871

Markus, H., \& Nurius, P. (1986). Possible selves. American Psychologist, 41, 954-959. https://doi.org/10.1037/0003-

066X.41.9.954

Neuman, W. L. (2016). Metodologi penelitian sosial: Pendekatan kualitatif dan kuantitatif (7 ed.). Jakarta: PT Indeks.

Nurchayati. (2010). Foreign exchange heroes or family builders? The life histories of three Indonesian women migrant workers. (Unpusblished Thesis), Ohio University, Athens.

Oppong, S. (2014). Between Bandura and Giddens: Structuration in social psychological research. Psychological Thought, 7, 111-123. https://doi.org/10.5964/psyct.v7i2.10 4

Pardita, D. P. Y., \& Sudibia, I. K. (2014). Dampak sosial, ekonomi, dan psikologis penderita HIV AIDS di kota Denpasar. Jurnal Studi Ekonomi Buletin, 19, 193-199. https://ojs.unud.ac.id/index.php/bse/a rticle/view/18814

Putra, M. B. A. (2016). Religiusitas dan kesejahteraan subyektif penderita HIV/AIDS perempuan di Surabaya. Psikologia: Jurnal Psikologi, 3, 125139.

https://doi.org/10.21070/psikologia.v $3 \mathrm{i} 1.117$

Rahakbauw, N. (2016). Dukungan keluarga terhadap kelangsungan hidup ODHA (Orang dengan HIV/AIDS). Insani, 3, 64-82. https://doi.org/10.31219/osf.io/7j63d

Ramadhan, A. S. (2018). Dipecat karena HIV-AIDS. Retrieved from https://rumahcemara.or.id/dipecatkarena-hiv-aids/

Ramadhani, Y. (2019). Diskriminasi dan stigma negatif penderita HIV/AIDS di tempat kerja. Retrieved from https://tirto.id/diskriminasi-danstigma-negatif-penderita-hivaids-ditempat-kerja-dd6b. 
Ryckman, R. M. (1997). Theories of personality $(6 \quad$ ed.). California: Brooks/Cole.

Swastika, Y. A. A., \& Masykur, A. M. (2017). Tabah sampai akhir: Sebuah studi kasus pada keluarga penderita HIV/AIDS. Jurnal Empati, 6, 424432.

https://ejournal3.undip.ac.id/index.ph p/empati/article/view/20114
Wertz, F. J., Charmaz, K., McMullen, L. M., Josselson, R., Anderson, R., \& McSpadden, E. (2011). Five ways of doing qualitative analysis: Phenomenological psychology, grounded theory, discourse analysis, narrative research, and intuitive inquiry. New York: The Guilford Press. 